\title{
Does Cassava-Based Farmers' Sociodemographic Characteristics and Perception Predict Adaptation Strategies to Climate Variability in Rain Forest and Derived Savannah Ecosystems of Nigeria?
}

\author{
Ayinde, Adefunke Fadilat O. ${ }^{1,2 *} \quad$ Johnston, Peter A. ${ }^{1} \quad$ Olujimi Olanrewaju O. ${ }^{3} \quad$ Dasgupta Purnamita $^{4}$ \\ 1.Climate System Analysis Group (CSAG), Department of Environmental and Geographical Sciences, \\ University of Cape Town, Cape Town, South Africa \\ 2.Department of Agricultural Administration, Federal University of Agriculture, Abeokuta (FUNAAB), P.M.B \\ 2240, Alabata, Abeokuta, Nigeria \\ 3.Department of Environmental Management and Toxicology, FUNAAB \\ 4.Environmental and Resource Economics Unit, Institute of Economic Growth, University of Delhi Enclave, \\ Delhi, India
}

\begin{abstract}
The study assessed the sociodemographic characteristics of cassava-based (CB) farmers' and their perception of climate variability as predictors of their adaptation strategies. The study covers cassava-based farmers in both the rain forest and derived savannah ecosystems of Nigeria. The study described the farmers' socioeconomic characteristics, their perception of climate variability, adaptation strategies and their socio-demographic factors influencing climate variability adaptation strategies. A cross-sectional survey using a multistage sampling procedure, was used to sample 400 cassava-based farmers in the study area. The data collected were analysed using descriptive statistics and multivariate probit (MVP) regression. Results indicated that $71.68 \%$ of the $\mathrm{CB}$ farmers were males, married $(85.21 \%)$, had primary school certificates $(30.08 \%)$ and received trainings in local adaptation strategy technologies (62.41\%) and climate adaptation strategies (65.16\%). Majority (68.67\%) felt climate variability implied low yield and reduced water supply for farming activities in some years $(69.42 \%)$. Most (85.21\%) CB farmers combatted climate variability through water management practices, $68.17 \%$ utilised weather forecast information while $44.86 \%$ adapted planting and harvesting time to target peak produce prices. Farmers' perception and their socioeconomic characteristics that predicted their climate variability strategies included access to extension training $(\mathrm{p}<0.01)$, experience of previous season's low yield $(\mathrm{p}<0.01)$, membership of professional associations $(\mathrm{p}<0.01)$, farming experience $(\mathrm{p}<0.10)$ and credit access $(\mathrm{p}<0.10)$. Cassava-based farmers' climate variability perception and their sociodemographic characteristics predicted their climate variability adaptation strategies. Enhancement trainings and improved formal credit access are veritable ways to minimise the adverse effects of climate variability on cassava production in the study area.
\end{abstract}

Keywords: Climate, Perception, Adaptation, Cassava farmers, Ecosystem, Multivariate probit.

DOI: $10.7176 / \mathrm{DCS} / 10-11-04$

Publication date: November $30^{\text {th }} 2020$

\section{Introduction}

Sustainable Development Goal (SDG) 13, emphasised effective adaptation to climate variability/change as a necessity that must be attended to, the world over, especially in developing countries. Hence, climate variability is so important in sub-Saharan Africa (SSA), such that it is closely linked to other important SDGs such as SDGs 1, 2 and 3 for no poverty, zero hunger as well as good health and wellbeing in the region due to their deep connection with SDG 13 (UN 2015a). The UN is resolute to urgently take the bold and transformative steps which are necessary to shift the world onto a sustainable and climate-resilient path (UN 2015b). Essentially, the achievement of these SDGs is critical, especially for SSA where the livelihoods of most households revolve around agriculture; of which climate variability posits major threat (Dube et al. 2016). This is more so as the United Nations (UN) has indicated, the year 2019 as a 'critical year' for climate action (UN 2019). Therefore, efforts to systematically tackle the challenges of climate variability and its possible adverse effects on farmers' livelihoods remain notable from the standpoint of policy, research and sustainable development.

The agricultural sector plays a major role in stimulating economic regeneration in Nigeria and to liberate the teaming population from the grip of poverty through improved quality of life. The place of cassava cultivation as a climate variability adaptation strategy cannot be overemphasised given its resilience to harsh soil and environmental conditions apart from its capability to support livelihood strategies against climate variability effects (Agwu et al. 2012; Mbanasor et al. 2015; Mupakati \& Tanyanyiwa 2017; Ayanlade et al. 2018). Climate variability and change pose a great risk to the sustainability of rain-fed agriculture (Agwu et al. 2012; IPCC 2013; Mbanasor et al. 2015), especially in Nigeria whose different vegetative zones are characterised mostly by temperature and rainfall (Odekunle et al. 2007). Rainfall is therefore, one of the key climatic variables, giving 
rise to a marked alternation of wet and dry seasons in most areas, as rain-fed agriculture constitute more than 95\% of farmed land in Africa (International Water Management Institute (IWMI 2019). This makes issue of climate variability and associated concerns an important subject of empirical investigation in an agriculturalbased economy (Adejuwon 2006).

Climate change/variability is one of the most pressing issues impacting on every facet of human lives, because of its implication on agricultural livelihood in the SSA region. In Nigeria, several research works (Odekunle et al. 2007; Adejuwon 2006; Agwu et al. 2012; Bose et al. 2014; Mbanasor et al. 2015; Babatolu \& Akinnubi 2016; Falola \& Achem 2017; Jellason et al. 2019) have been conducted to understand the levels of awareness and perception of smallholder agricultural workers to climate change/variability issues, as well as studies on associated farm-level coping and adaptation strategies employed by farmers. Agricultural adaptation studies to climate variability aims at developing appropriate coping mechanisms to address the negative impacts of climate variability of the livelihoods of farmers and households (Zeirvogel et al. 2008). At the farm level in Nigeria, Bose et al. (2014) reported that farmers in southwest Nigeria had perceived changes in the climate parameters through the decrease in rainfall pattern, increase in pest infestation in both crops and animals, heavy loss of pasture land and premature ripening of crops (Tambo \& Abdoulaye 2013), while in the northern part, through increased temperature, unpredictable, erratic, heavy and increased rainfall, late-onset and early retreat of rains (Babatolu \& Akinnubi, 2016; Falola \& Achem 2017; Jellason et al. 2019).

Similar studies have worked on the effect of climate variability and adaptation strategies on cassava production systems as well as farmers' productivity using different analytical approaches. For example, Agwu et al., (2012) adopted the Cobb-Douglas regression model while Asadu et al. (2014) adopted an experimental approach. Furthermore, Boansi (2017) adopted use of co-integration analysis while Dereje and Nega (2019) adopted Chi-square and binary logistic regression analyses. This study therefore, added to the existing body of knowledge by studying cassava-based farmers' perception and the sociodemographic precursors of their adaptation strategies using the multivariate probit analysis. Specifically, the study:

1. Described cassava-based farmers' socioeconomic characteristics.

2. Described cassava-based farmers' perception of climate variability.

3. Identified the various adaption strategies employed by the cassava-based farmers.

4. Determined the socio-demographic factors influencing climate variability adaptation strategies of cassava-based farmers in the study area.

\section{Methodology}

Area of study

The study was conducted in mid-2017, targeting cassava-based farmers in the rain forest and derived savannah agro-ecological zones of Nigeria while using Ogun and Kwara States as the study locations.

Abeokuta, the capital city of Ogun State lies between latitude $7^{\circ} 06^{\prime}$ and $7^{\circ} 13^{\prime} \mathrm{N}$ and longitudes $3^{\circ} 15^{\prime}$ and 3 ${ }^{\circ} 25^{\prime} \mathrm{E}$ in the tropical rain forest and South-western part of Nigeria. The climate of the study area is tropical with a distinct wet season (April-October) and a dry season (November-March) with two peak rainfall periods (Aladenola \& Adeboye 2010). Figure 1 shows the scaled map of Ogun State.

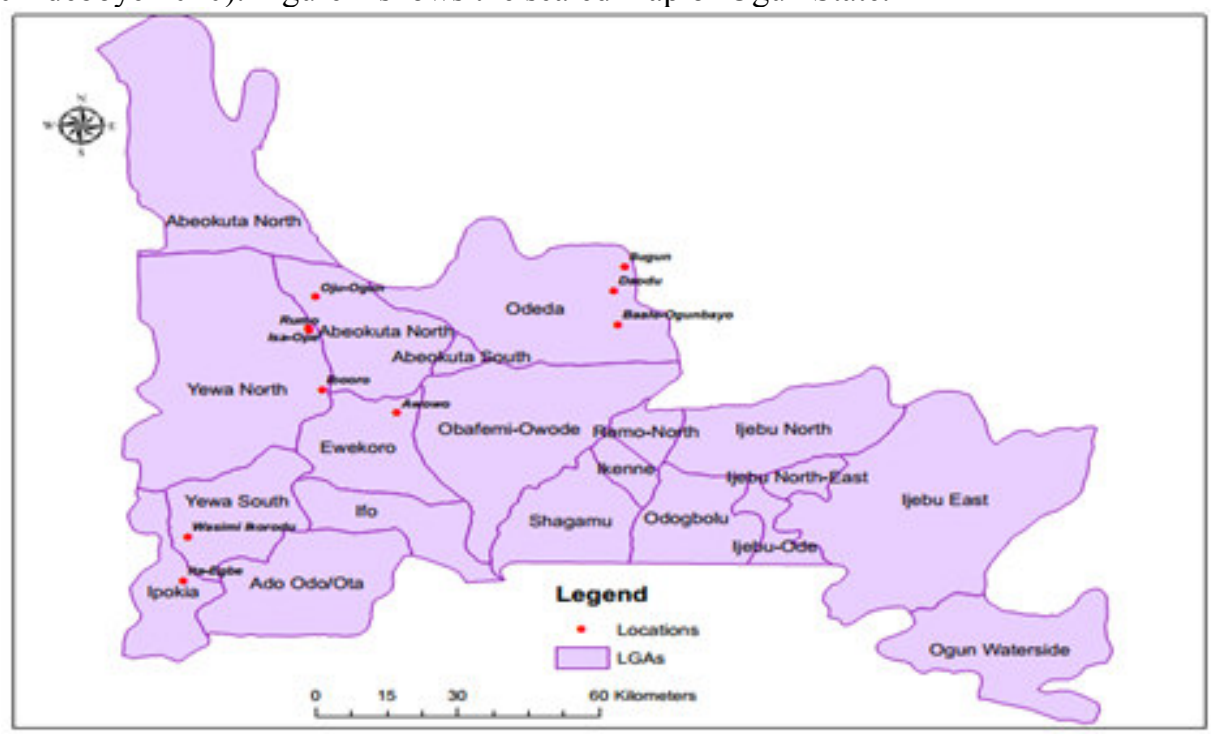

Fig 1: GPRS Location Map of Ogun State, showing the study area

Ilorin, the capital of Kwara State lies between latitude of $8^{\circ} 28^{\prime} 47.56^{\prime \prime}$ and longitude of $4^{\circ} 32^{\prime} 30.53^{\prime \prime}$ and it is located in the middle-belt region of Nigeria. Its rainfall distribution peaks between September and early October. 
The soil in the area is ferruginous and has the tendency of being more productive if not for its water deficiency. Its vegetation is characterised by wooded savannah grassland also known as derived savannah (or derived Guinea savannah) due to the transformation caused by the decline in precipitation and human activities such as shifting cultivation, indiscriminate logging/bush clearing, overgrazing by cattle (Oriola et al. 2010). The common trees are shea butter tree (Vitalera paradosa) and locust bean tree (Parkia biglobosa). While the grains grown in the area include millets, maize, sorghum and rice, common root crops found in this area are yam, cassava, potatoes and cocoyam (Oriola et al. 2010).

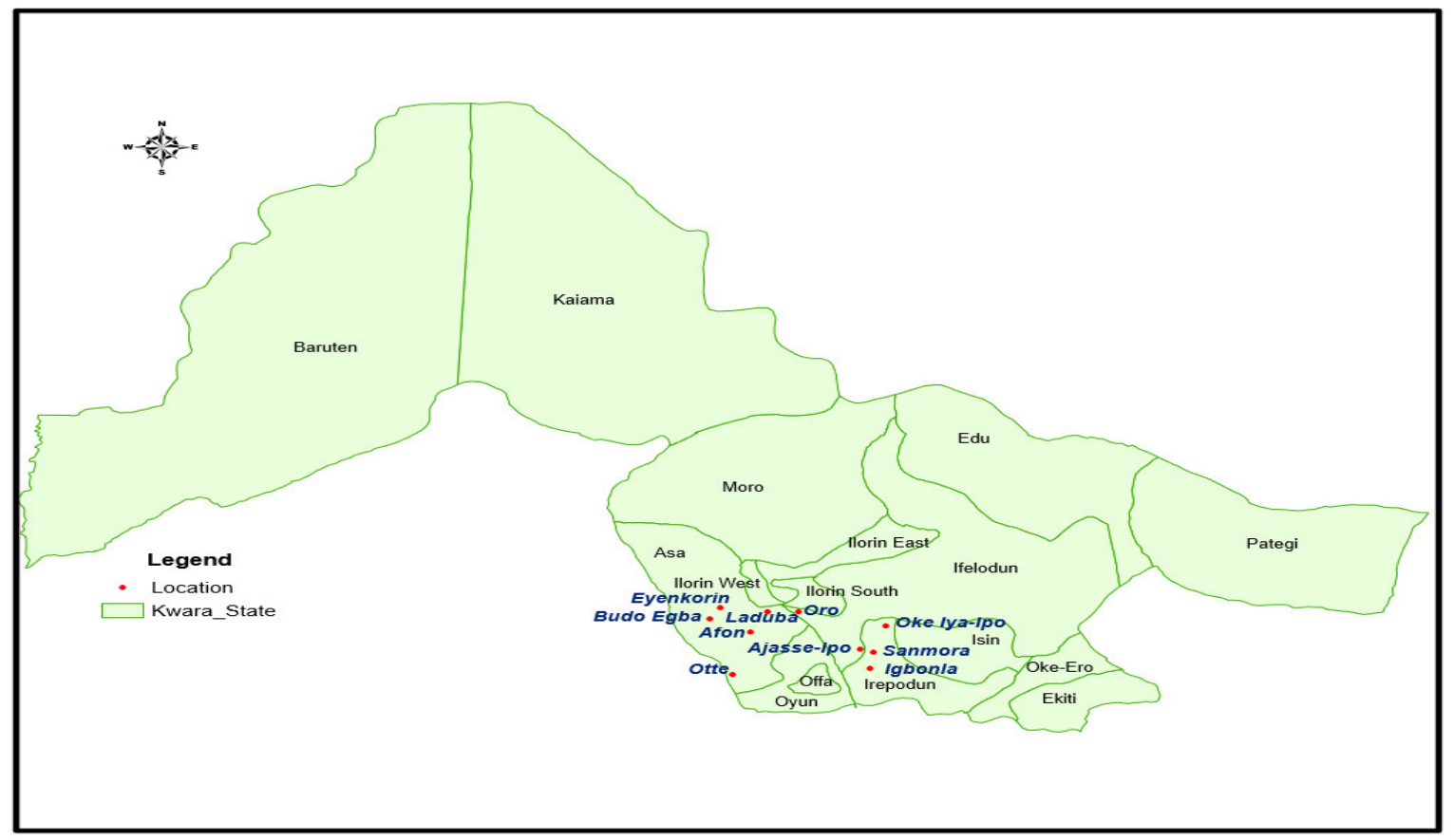

Fig 2: GPRS Location Map of Kwara State, showing the study area

Data:

Farmers quantitative data were obtained with the use of interview guide. The data collected included respondents' socio-economic data, perception on climate variability adaptation strategies and livelihood coping strategies, among others. The survey guide used for quantitative data collection was adapted from Ogunbameru et al. (2013) and Ibrahim et al. (2015).

Data Sampling and Analysis

Sampling used in the study followed the zoning system of the Agricultural Development Programmes (ADPs) in both States. A multi-stage sampling technique was adopted to select respondents for this study. In stage one, Ogun and the Kwara States were selected in the rain forest vegetation and derived savannah vegetation respectively, using a simple random sampling technique. In the second stage, two zones apiece (constituting 50\% each) were selected through a simple random sampling technique from the existing ADP zones in both states. In the third stage, one sub-location (block) was selected per zone (making two blocks for each state), making four blocks altogether. In the fourth stage, five villages were selected from each block to give ten villages per state and 20 villages in all. In the fifth stage, twenty households were selected per village through a systematic random sampling technique to give a total sample size of 400 respondents.

Descriptive statistics and inferential statistics were used for this study. Descriptive statistics (frequency and percentages tables) were used to describe the socio-economic characteristics of respondents and their perception of the effects of climate variability on farming activities and adaptation strategies adopted.

The multivariate probit regression model was applied to determine the socio-demographic factors influencing adoption of farmers' climate variability strategies in the study areas. Adoption of multivariate probit regression was motivated given that the choice of adaptation strategies is not mutually exclusive such that a farmer can adopt more than one set of strategies at a time. This contemporaneous peculiarity is accommodated in the multivariate framework. The multivariate probit regression model is stated in Equation 1: 


$$
\begin{aligned}
& C_{i j}^{*}=X_{i j} \beta_{j}+e_{i j} \\
& C_{i j}=\left\{\begin{array}{l}
1 \text { if } C^{*}{ }_{i j}>0 \\
0 \text { if } C^{*}{ }_{i j} \leq 0
\end{array}\right.
\end{aligned}
$$

$e_{i j}, j=1, \ldots J$ are multivariate normal distributed error terms distributed, each with a zero mean and variance-covariance matrix $Q$. Each of the elements of the principal diagonal of $Q$ has a value of 1 , and correlations $\rho \mathrm{jm}=\rho \mathrm{mj}$ as off-diagonal elements. There are four mutually inclusive strategies from which

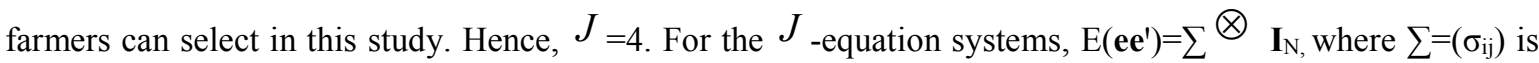
four by four positive-definite matrix and $\otimes$ is the Kronecker products of the two matrices (Cameron \& Trivedi 2010).

Where:

$\mathrm{C}_{\mathrm{ij}}=1$ if farmer $\mathrm{i}$ adopts adaptation strategy $\mathrm{j}, 0$ otherwise

$\mathrm{X}_{1}=$ State $(1$ if Ogun State, 0 otherwise)

$\mathrm{X}_{2}=$ Age of the farmer (years)

$\mathrm{X}_{3}=$ Marital status of the farmer ( 1 if married, 0 otherwise)

$\mathrm{X}_{4}=$ Sex of the farmer ( 1 for male, 0 for female)

$\mathrm{X}_{5}=$ Farm experience (years)

$\mathrm{X}_{6}=$ Farmer's association ( 1 if the farmer is a member of an association, 0 otherwise)

$\mathrm{X}_{7}=$ Household size of the farmer (number of people)

$\mathrm{X}_{8}=$ Credit facility ( 1 if the farmer has access to a credit facility, 0 otherwise)

$\mathrm{X}_{9}=$ Access to extension services ( 1 if farmer have access to extension services, 0 otherwise)

$\mathrm{X}_{10}=$ Education (years spent in acquiring formal education)

$\mathrm{X}_{11}=$ Previous experience of late rainfall ( 1 if farmer has experienced periods of late rainfall before, 0 otherwise)

$\mathrm{X}_{12}=$ Previous experience on low crop yield due to climate variability ( 1 if the farmer had previously experienced low crop yield due to unstable climate variability, 0 otherwise)

\section{Results and Discussion}

Socio-demographic Characteristics of Respondents:

The mean age of the farmers was approximately 47 years, and most of them $(64.41 \%)$ were within 31 and 60 years age bracket (Table 1). This suggests that the farmers were in the active age groups and were expected to be able to maximise farm labour productivity, ceteris paribus. Most (85.21\%) respondents were married with a mean household size of eight (8) persons, suggesting availability of family labour for farming activities, as a complement to hired labour. Majority (77.97\%) of the cassava-based farmers belonged to farmers' professional groups, which gives farmers the advantage of access to some benefits (such as access to improved seeds, fertilisers, credit and new production information) and attendant enhancement of their farm production. Furthermore, $54.39 \%$ of the respondents had less than secondary school education. This may affect the ability to efficiently combine resources to manage farm production when confronted with the negative effects of climate variability (Dereje \& Nega 2019). Over 70\% of the farmers were males, suggesting that cassava-based farming enterprise was male dominated in the study area. Similarly, $86.72 \%$ of the farmers reported that they had access to credit. This was mainly the local, non-institutional sources of credit, some of which included loan from friends and family members, credit purchase of input (for later payment) and contributory credit. Also, most $(65.16 \%)$ of the farmers have received agricultural extension training on adaptation strategies to climate variability. Extension access is a common feature among many smallholder farmers especially in Southwest and Northern Nigeria contrary to (Ziervogel et al. 2008) who opined that little is known empirically about the role of agricultural extension training in enhancing adaptation strategy adoption in Nigeria. 
Table 1: Distribution of respondents by socio-demographic characteristics

\begin{tabular}{|c|c|c|}
\hline Variables & Frequency & Percentage \\
\hline \multicolumn{3}{|l|}{ Age } \\
\hline Less than 31 & 74 & 18.55 \\
\hline $31-45$ & 147 & 36.84 \\
\hline $46-60$ & 110 & 27.57 \\
\hline $61-1000$ & 68 & 17.04 \\
\hline \multicolumn{3}{|l|}{ Household size } \\
\hline 1 to 5 & 112 & 28.07 \\
\hline 6 to 10 & 191 & 47.87 \\
\hline 10 to 15 & 73 & 18.3 \\
\hline above 15 & 23 & 5.77 \\
\hline \multicolumn{3}{|l|}{ Education } \\
\hline No formal education & 97 & 24.31 \\
\hline Primary & 120 & 30.08 \\
\hline Secondary & 96 & 24.06 \\
\hline Tertiary & 86 & 21.55 \\
\hline \multicolumn{3}{|c|}{ Received training on local strategy technology } \\
\hline No & 150 & 37.59 \\
\hline Yes & 249 & 62.41 \\
\hline \multicolumn{3}{|c|}{ Access to credit facilities } \\
\hline No & 53 & 13.28 \\
\hline Yes & 346 & 86.72 \\
\hline \multicolumn{3}{|c|}{ Farmers association membership } \\
\hline No & 88 & 22.06 \\
\hline Yes & 311 & 77.94 \\
\hline \multicolumn{3}{|c|}{ Received adaptation strategies training by extension agents } \\
\hline Yes & 260 & 65.16 \\
\hline No & 139 & 34.84 \\
\hline \multicolumn{3}{|l|}{ Sex of household head } \\
\hline Male & 286 & 71.68 \\
\hline Female & 113 & 28.32 \\
\hline \multicolumn{3}{|l|}{ Marital status } \\
\hline Single & 36 & 9.02 \\
\hline Married & 340 & 85.21 \\
\hline Widowed & 19 & 4.76 \\
\hline others & 4 & 1 \\
\hline Total & 399 & 100 \\
\hline
\end{tabular}

Perceived Effects of Climate Variability on Farm Production by Cassava-based Farmers:

The perception of cassava-based farmers on the effects of climate variability on their farm production are presented in Table 2. Approximately $69.0 \%$ of the farmers reported that climate variability resulted in water shortage and yield reduction over the years. This finding agrees with empirical studies reported in different parts of Nigeria (Bose et al. 2014; Falola \& Achem 2017; Jellason et al. 2019). Approximately 25\% of the farmers reported damage to cassava crops due to variability in climate while 6.77 reported pest infestation. These challenges pose enormous implications for research, extension, and communication on climate-related information to enable farmers to minimise loss of farm production and income.

Table 2: Farmers perception of the effects of climate variability on farm production

\begin{tabular}{lcc}
\hline Variables & Frequency* & Percentage \\
\hline Change in rainfall pattern affects (have reduced) & water availability for & \\
farming in some years & 277 & 69.42 \\
I have been experiencing low yield from my cassava-based farms in & 274 & 68.67 \\
some years & & 6.77 \\
Climate variability has resulted in pest infestation & 27 & 25.06 \\
Crop Damage (Cassava) & 100 & \\
\hline
\end{tabular}

\footnotetext{
*Multiple responses
} 


\section{Adaptation Strategies Employed by Farmers to Perceived Adverse Effects of Climate Variability}

The distribution of respondents according to farm-level adaptation strategies employed to perceived adverse effects of climate variability is shown in Table 3. Most (85.21\%) of the farmers adopted water harvesting scheme (such as ridging across the slope, use of tie-ridges, etc.) while $68.17 \%$ adopted weather forecast information strategy. Fewer (44.86\%) farmers targeted planting of crops and harvesting time to periods that command higher output prices. Also, $41.10 \%$ of the farmers adopted soil amendment strategy (such as crop rotation) to reduce adverse effects of climate variability. The local strategies adopted by the cassava-based farmers in the study area abound in literature (Ziervogel et al. 2008; Ogunbameru et al. 2013; Mupakati \& Tanyanyiwa 2017; Mahouna et al. 2018).

Table 3: Farm-level adaptation strategies used by farmers to combat perceived effects of climate variability

\begin{tabular}{lcc}
\hline Adaptation measures & *Frequency & Percentage \\
\hline Use of soil amendment practices (Crop rotation) & 164 & 41.10 \\
Use of water management practices & 340 & 85.21 \\
Use of weather forecast information & 272 & 68.17 \\
$\begin{array}{l}\text { Adapt planting and harvesting time to period that } \\
\text { commands higher output prices }\end{array}$ & 179 & 44.86 \\
\hline
\end{tabular}

* Multiple Responses

Famers Perception and Socio-demographic Factors Predicting Climate Variability Adaptation Strategies of Cassava-based Farmers

The estimated multivariate probit regression model (Table 4) shows an estimated value of the log-likelihood function (-862.837) and the Wald Chi square statistics (135.16) which was significant $(\mathrm{p}<0.01)$, implying overall significance of the model that the model's explanatory variables (soil amendment, water harvesting scheme, use of weather forecast information and targeting planting and harvesting activities at periods expected to commands higher prices) jointly explained the likelihood of selecting the adaptation strategies employed by farmers in the study area.

The coefficient of location of the cassava-based farmer has a significant and positive relationship with the likelihood of employing soil amendment $(p<0.10)$, water management practices $((p<0.01)$ and weather forecast information $(p<0.01)$ as strategies to mitigate potentially adverse effects of climate on their farms. This means that cassava-based farmers in Ogun State have higher chances of employing all these strategies than farmers in Kwara State. This may be as a result of higher rainfall pattern occasioning the nature of the soil in these areas (as a result of ecological variation). Loranty et al. (2016) opined that processes that resulted in vegetation change (such as ecosystem responses to climatic elements) have potential effects on crop productivity.

Household size negatively affects farmers' choice of targeting production and harvesting activities at the period that command higher prices $(\mathrm{p}<0.10)$. Increased household size imposes urgency of farmers to produce at the earliest available time in order to have food on their table (Okonkwo et al. 2015).

Farmers' association membership has a significant negative relationship with the choice of soil amendment applied $(\mathrm{p}<0.01)$. Also, access to credit increased the chances of farmers' adaptation strategy. This implies that membership of farmers' organisation allows farmers ease of access to technical information and group finance for use of soil amendments (Wood et al. 2014).

Access to extension training by farmers significantly and positively influence all the choices of adaptation strategies modelled in the equation. This shows the ramifying implication of the need for a viable and virile extension service delivery in the mitigation of climate variability by farmers (Asrat \& Simane 2018).

Furthermore, late rainfall experience has a significant positive relationship $(p<0.10)$ with usage of weather forecast information. This means that the more the farmers experience late rainfall, the more their chances of employing this strategy in order to prevent avoidable crop failure. In the same vein, age of farmers $(\mathrm{p}<0.01)$ and prior experience of low yield $(\mathrm{p}<0.01)$ have a significant positive relationship with targeting production and harvesting activities at the period that command higher prices. Age and experience impose more wisdom on farmers over the years to adopt techniques that prompt higher farm productivity (Okonkwo et al. 2015). 
Table 4: Farmers perception and socio-demographic determinants of the choice of livelihood adaptation strategies

\begin{tabular}{|c|c|c|c|c|}
\hline Explanatory Variable & Soil Amendment & \begin{tabular}{l}
\multicolumn{1}{c}{ Water } \\
Management \\
practices
\end{tabular} & $\begin{array}{l}\text { Weather forecast } \\
\text { Information }\end{array}$ & $\begin{array}{l}\text { Adjusting the } \\
\text { Planting and } \\
\text { Harvesting } \\
\text { Period }\end{array}$ \\
\hline State (Ogun dummy) & $\begin{array}{l}* 0.268 \\
(0.148)\end{array}$ & $\begin{array}{r}* * * 0.590 \\
(0.188)\end{array}$ & $\begin{array}{r}* * * 0.816 \\
(0.159)\end{array}$ & $\begin{array}{r}0.175 \\
(0.148)\end{array}$ \\
\hline Age & $\begin{array}{r}-0.005 \\
(0.007)\end{array}$ & $\begin{array}{r}0.011 \\
(0.009)\end{array}$ & $\begin{array}{r}-0.001 \\
(0.007)\end{array}$ & $\begin{array}{r}* * * 0.023 \\
(0.007)\end{array}$ \\
\hline $\begin{array}{l}\text { Marital Status (Married } \\
\text { dummy) }\end{array}$ & $\begin{array}{r}-0.171 \\
(0.189)\end{array}$ & $\begin{array}{r}-0.108 \\
(0.257)\end{array}$ & $\begin{array}{r}-0.140 \\
(0.204)\end{array}$ & $\begin{array}{r}-0.154 \\
(0.192)\end{array}$ \\
\hline Sex (male dummy) & $\begin{array}{r}0.129 \\
(0.136)\end{array}$ & $\begin{array}{r}0.094 \\
(0.191)\end{array}$ & $\begin{array}{r}0.151 \\
(0.153)\end{array}$ & $\begin{array}{r}0.173 \\
(0.142)\end{array}$ \\
\hline Farming Experience & $\begin{array}{r}0.004 \\
(0.006)\end{array}$ & $\begin{array}{r}0.006 \\
(0.008)\end{array}$ & $\begin{array}{r}0.000 \\
(0.007)\end{array}$ & $\begin{array}{l}-0.013 \\
(0.307)\end{array}$ \\
\hline Membership of Association & $\begin{array}{r}* * *_{-}-0.624 \\
(0.157)\end{array}$ & $\begin{array}{r}-0.325 \\
(0.214)\end{array}$ & $\begin{array}{r}-0.040 \\
(0.167)\end{array}$ & $\begin{array}{r}0.115 \\
(0.160)\end{array}$ \\
\hline Household Size & $\begin{array}{r}3.0 \mathrm{e}^{-4} \\
(0.018)\end{array}$ & $\begin{array}{r}-0.026 \\
(0.021)\end{array}$ & $\begin{array}{r}-0.032 \\
(0.018)\end{array}$ & $\begin{array}{r}*_{-}-0.031 \\
(0.018)\end{array}$ \\
\hline Access to Credit & $\begin{array}{l}* 0.366 \\
(0.210)\end{array}$ & $\begin{array}{r}0.257 \\
(0.232)\end{array}$ & $\begin{array}{r}-0.188 \\
(0.217)\end{array}$ & $\begin{array}{r}0.329 \\
(0.204)\end{array}$ \\
\hline $\begin{array}{ll}\text { Extension } & \text { Training } \\
\text { (dummy) } & \end{array}$ & $\begin{aligned} * * 0.361 \\
(0.142)\end{aligned}$ & $\begin{array}{r}* * * 0.663 \\
(0.172)\end{array}$ & $\begin{array}{r}* * * 0.485 \\
(0.146)\end{array}$ & $\begin{array}{r}* 0.250 \\
(0.141)\end{array}$ \\
\hline $\begin{array}{l}\text { Education (Years of } \\
\text { Schooling) }\end{array}$ & $\begin{array}{r}-0.009 \\
(0.009)\end{array}$ & $\begin{array}{r}0.005 \\
(0.011)\end{array}$ & $\begin{array}{r}0.000 \\
(0.009)\end{array}$ & $\begin{array}{r}-0.013 \\
(0.009)\end{array}$ \\
\hline $\begin{array}{l}\text { Experienced late onset of } \\
\text { rainfall previously } \\
\text { (dummy) }\end{array}$ & $\begin{array}{r}0.090 \\
(0.148)\end{array}$ & $\begin{array}{r}0.266 \\
(0.185)\end{array}$ & $\begin{array}{r}* 0.288 \\
(0.159)\end{array}$ & $\begin{array}{r}-0.173 \\
(0.149)\end{array}$ \\
\hline $\begin{array}{l}\text { Experienced low yield } \\
\text { previously (dummy) }\end{array}$ & $\begin{array}{r}0.229 \\
(0.195)\end{array}$ & $\begin{array}{r}-0.188 \\
(0.250)\end{array}$ & $\begin{array}{r}0.144 \\
(0.223)\end{array}$ & $\begin{array}{r}* * * 0.812 \\
(0.209)\end{array}$ \\
\hline Constant & $\begin{array}{r}-0.201 \\
(0.429)\end{array}$ & $\begin{array}{r}-0.139 \\
(0.545)\end{array}$ & $\begin{array}{r}0.103 \\
(0.458)\end{array}$ & $\begin{array}{l}-1.088 \\
(0.437)\end{array}$ \\
\hline $\begin{array}{l}\text { Log likelihood } \\
\text { Wald Chi square } \\
\text { Prob }>\text { chi } 2\end{array}$ & $\begin{array}{r}-862.837 \\
135.16 \\
0.0000\end{array}$ & & & \\
\hline
\end{tabular}

Standard errors in the parenthesis, *** - Coefficients significant at 1\%, ** - Coefficients significant at 5\%, * Coefficients significant at $10 \%$

\section{Conclusion}

The issues of climate variability and its effects on the livelihoods of farmers have continued to be a prime focus globally. In this study, the perception of 400 cassava-based farmers concerning climate variability, adaptation measures employed to combat the adverse effects of climate variability as well as their perception and sociodemographic characteristics determining choice of adaptation strategies were examined. The study concluded locational variation in adaptation strategies employed by farmers while farmers' sociodemographic characteristics (such as age, membership of farmers' associations, access to credit and extension training) and the way they perceived climate variability were prime determinants of adaptation techniques employed by them to mitigate effects of climate variability.

Both the States and Federal Governments of Nigeria have roles to play in enhancing state-of-the-art extension delivery system that continues to provide out-of-school training to farmers for farm productivity enhancement. Ogun and Kwara States Ministries of Community Development and Cooperatives should provide enabling environment to farmers' cooperatives for enhanced access to credit, in order to stimulate choice adaptation strategies that minimises the adverse effects of climate variability on farm production while enhancing farmers' food security and livelihoods.

\section{Acknowledgements}

This research work was sponsored by the Association of Commonwealth Universities (ACU) in collaboration with UK Aids and African Academy of Sciences in Nairobi, Kenya under the Climate Impact Research Capacity 
Leadership Enhancement (CIRCLE) Visiting Fellowships for the "Cohort 3" programme. The Fellowship was accomplished in affiliation with the African Climate Development Initiative (ACDI), University of Cape Town (UCT), Cape Town, South Africa, Vitae and Natural Resources Institute, University of Greenwich, UK.

I am also greatly indebted to my University, College and Department for releasing me to undertake this fellowship. Further, I wish to appreciate Profs. A. Babatunde, Gina Ziervogel and Toyin Opeolu; Drs. S. Lawal, V. Ongoma, A. Makinde, D. Akerele, Shakirat B. Ibrahim, I. Adefeso, Khadijat Daud, Alaba M. Dare; as well as Oyin R. Ogunpaimo, R. O. Aminu and B. A. Esayas, CIRCLE team/alumni, ACDI family, UCT Research Office team, EGS staff/researchers, for their supports at various stages of the study. Gratitude also goes to the extension officers (Messrs. E. Ojo, J. Oyegunle, M. Sheu and Dr. Tawakalt Abiola and other OGADEP and KWADEP staff) and FUNAAB postgraduate students (field assistants).

\section{References}

Adejuwon, J. O. (2006). Food crop production in Nigeria. II: Potential effects of climate change. Climate Research, 32, 229-245.

Agwu, N., Nwachukwu, I. N.\& Anyawu, C. (2012). Climate variability: Relative effect on Nigeria's cassava productive capacity. Gallup Report, 4(2), 11-14.

Aladenola, O. O. \& Adeboye, O. B. (2010). Assessing the potential for rainwater harvesting. Water Resources Management, 24(10), 2129-2137. https://doi.org/10.1007/s11269-009-9542-y

Asadu, C. I. A., Dixon, A. G. O. \& Eze, S. C. (2014). Evaluation of cassava-based systems for adaptation to climatic variations in Eastern Nigeria. Agro-Science: Journal of Tropical Agriculture, Food, Environment and Extension, 13(2), 37-42.

Asrat, P. \& Simane, B. (2018). Farmer's perception of climate change and adaptation strategies in the Dabus watershed, North-west Ethiopia. Ecological Processes, 7(7). Online. https://doi.org/10.1186/s13717-0180118-8

Ayanlade, A., Radeny, M., \& Akin-Onigbinde A. I. (2018). Climate variability/change and attitude to adaptation technologies: a pilot study among selected rural farmers' communities in Nigeria. GeoJournal, 83(2), 319331. https://doi.org/10.1007/s10708-017-9771-1

Babatolu J. S., \& R. T. Akinnubi (2016): Smallholder farmers' perception of climate change and variability impact and their adaptation strategies in the Upper and Lower Niger River Basin Development Authority Areas, Nigeria. Journal of Petroleum and Environmental Biotechnology, 7: 279. https://doi:10.4172/21577463.1000279

Boansi, D. (2017). Effect of climatic and non-climatic factors on cassava yields in Togo: Agricultural policy implications. Climate, 5(28), 1-21, MDPI Publishers.

Bose, M. M., Abdullah, A. M., Harun R, Jamalani M. A., Elawad R. E., \& Fallah, M. (2014). Perception of and adaptation to climate change by farmers in the semi-arid zone of North-eastern Nigeria. IOSR Journal of Environmental Science, Toxicology and Food Technology, 8(11), 52-57.

Cameron, A. C., \& Trivedi, P. K. (2010). Microeconometrics using Stata. Revised edition. College Station, TX: Stata Press.

Dereje, T. R. \& Nega, A. A. (2019). Determinants of climate change mitigation and adaptation strategies: An application of protection motivation theory. Rural Sustainability Research, 42(337), 9-25, Sciendo,

Dube, T., Moyo, P., Ncube, M., \& Nyathi, D. (2016). The impact of climate change on agro-ecological based livelihoods in Africa: A review. Journal of Sustainable Development, 9(1), 256-267.

Falola, A., \& Achem, B. A. (2017). Perceptions on climate change and adaptation strategies among sweet potato farming households in Kwara State, Northcentral Nigeria. Ceylon Journal of Science, 46(3), 55-63. http://doi.org/10.4038/cjs.v46i3.7443

Ibrahim, S. B., Ayinde, I. A., \& Arowolo, A. O. (2015). Analysis of arable crop farmers' awareness to causes and effects of climate change in South-western Nigeria. International Journal of Social Economics, 42(7), 614-628. http://dx.doi.org/10.1108/IJSE-09-2013-0201

IPCC (2013). Climate Change 2013: The Physical Science Basis. Contribution of Working Group I to the Fifth Assessment Report of the Intergovernmental Panel on Climate Change [Stocker, T. F., Qin, D., Plattner, G.K., Tignor, M., Allen, S. K., Boschung, J., Nauels, A., Xia, Y., Bex, V., and Midgley, P. M. (eds.)]. Cambridge University Press, Cambridge, United Kingdom and New York, NY, USA, 1535 pp.

IWMI (2019). Rain-fed agriculture summary. http://www.iwmi.cgiar.org/issues/rainfed-agriculture/summary/ Downloaded on 29 June 2019. International Water Management Institute

Jellason, N. P., Baines, R., Conway, J., \& Ogbaga, C. C. (2019). Climate change perceptions and attitudes to smallholder adaptation in North-western Nigerian drylands. Social Sciences, 8(2), 31. https://doi.org/10.3390/socsci8020031

Loranty, M. M., Lieberman-Cribbin, W., Berner, L. T., Natali, S. M., Goetz, S. J., Alexander, H. D. \& Kholodov, A. L. (2016). Spatial variation in vegetation productivity trends, fire disturbance, and soil carbon across 
arctic-boreal permafrost ecosystems. Environmental Research Letters, 11(9). https://iopscience.iop.org/article/10.1088/1748-9326/11/9/095008/pdf

Mahouna, A., Fadina, R., \& D. Barjolle (2018): Farmers' adaptation strategies to climate change and their implications in the Zou Department of South Benin. Environments, 5(15), pp 1-17; https://doi:10.3390/environments5010015

Mbanasor, J. A., Nwachukwu, I. N., Agwu, N. M. \& Onwusiribe, N. M. (2015). Impact of climate change on the productivity of cassava in Nigeria. Journal of Agriculture and Environmental Sciences, 4(1), 138-147.

Mupakati, T. \& V. I. Tanyanyiwa (2017): Cassava production as a climate change adaptation strategy in Chilonga Ward, Chiredzi District, Zimbabwe. Jàmbá: Journal of Disaster Risk Studies, 9(1), pp 1-10; a348. https://doi.org/10.4102/jamba.v9i1.348

Odekunle, T.O, Orinmoogunje, I. O. O. \& Ayanlade, A. (2007) Application of GIS to assess rainfall variability impacts on crop yield in Guinean Savanna part of Nigeria. African Journal of Biotechnology, 6(18), 21002113.

Okonkwo, E. A., Arua, R. N. \& Agbo, F. U. (2015). Effects of climate variability on the choices of livelihood among farm households in Anambra State, Nigeria. African Journal of Agricultural Research, 10 (44), 4134-4141. https://academicjournals.org/journal/AJAR/article-abstract/B97B2E256035

Ogunbameru, B. O., Mustapha, S. B. \& Idrisa, Y. L. (2013). Capacity building for climate change adaptation: modules for agricultural extension curriculum department. Russian Journal of Agricultural and Socioeconomic Sciences, 2(14), 61-66.

Oriola, E. O., Ifabiyi, I. P. \& Hammed, A. T. (2010). Impact of reforestation in a part of degrading natural ecological system of Ilorin, Kwara State, Nigeria. African Journal of Agricultural Research, 5(20), 28112816.

Tambo, J. \& Abdoulaye, T. (2013). Smallholder farmers' perceptions of and adaptations to climate change in the Nigerian savannah. Regional Environmental Change, 13(2), 375-388. https://doi.org/10.1007/s10113-0120351-0

UN (2015a). 2030 agenda for sustainable development, United Nations.

UN (2015b). Transforming our world: The 2030 agenda for sustainable development, the United Nations. https://www.un.org/sustainabledevelopment/development-agenda

UN (2019). Sustainable Development Goals. United Nations, Department of Economic and Social Affairs. https://www.un.org/development/desa/publications/sustainable-development-goals-report-2019.html

Wood, S. A., Jina, A. S., Jain, M., Kristjanson, P. \& DeFries, R. S. (2014). Smallholder farmer cropping decisions related to climate variability across multiple regions. Global Environmental Change, 25, 163-172. Online. https://doi.org/10.1016/j.gloenvcha.2013.12.011

Ziervogel, G., Cartwright, A., Tas, A., Adejuwon, J., Zermoglio, F., Shale, M. \& Smith, B. (2008). Climate change and adaptation in African agriculture. Stockholm: SEI. Report for the Rockefeller Foundation. 